\title{
Twospotted Spider Mite, Tetranychus urticae Koch (Arachnida: Acari: Tetranychidae) ${ }^{1}$
}

Thomas R. Fasulo and H. A. Denmark ${ }^{2}$

\section{Introduction}

The twospotted spider mite, Tetranychus urticae Koch, has been controversial in its taxonomic placement. About 60 synonyms included under this species have compounded the controversy.

The body of a spider mite is separated into two distinct parts: (1) the gnathosoma and (2) the idiosoma. The gnathosoma includes only the mouthparts. The idiosoma is the remainder of the body and parallels the head, thorax and abdomen of insects. After hatching from the egg, the first immature stage (larva) has three pair of legs. The following nymphal stages and the adult have four pairs of legs.

\section{Distribution}

The twospotted spider mite was originally described from European specimens. It is considered to be a temperate zone species, but it is also found in the subtropical regions. It is found throughout the USA in greenhouses where it survives the winters beyond its natural limits. Tuttle and Baker (1968) report this species to be found on deciduous fruit trees in northern regions of the U.S. and Europe.

\section{Description}

The twospotted spider mite is oval in shape, about 1/50 inch long and may be brown or orange-red, but a green, greenish-yellow or an almost translucent color is the most common. The female is about $0.4 \mathrm{~mm}$ in length with an elliptical body that bears 12 pairs of dorsal setae. Overwintering females are orange to orange-red. The body contents (large dark spots) are often visible through the transparent body wall. Since the spots are accumulation of body wastes, newly molted mites may lack the spots. The male is elliptical with the caudal end tapering and smaller than the female. The axis of knob of aedeagus is parallel or forming a small angle with axis of shaft.

\section{Life Cycle}

Spider mite development differs somewhat between species, but a typical life cycle is as follows. The eggs are attached to fine silk webbing and hatch in approximately three days. The life cycle is

1. This document is EENY-150 (originally published as DPI Entomology Circular 89), one of a series of Featured Creatures from the Entomology and Nematology Department, Florida Cooperative Extension Service, Institute of Food and Agricultural Sciences, University of Florida. Published: August 2000. This document is also available on Featured Creatures Website at http://creatures.ifas.ufl.edu. Please visit the EDIS Website at http://edis.ifas.ufl.edu. Additional information on these organisms, including many color photographs, is available at the Entomology and Nematology Department website at http://entnemdept.ifas.ufl.edu/.

2. Thomas R. Fasulo, Entomology and Nematology Department, University of Florida and H. A. Denmark, Florida Department of Agriculture and Consumer Services, Division of Plant Industry, Gainesville, FL. 


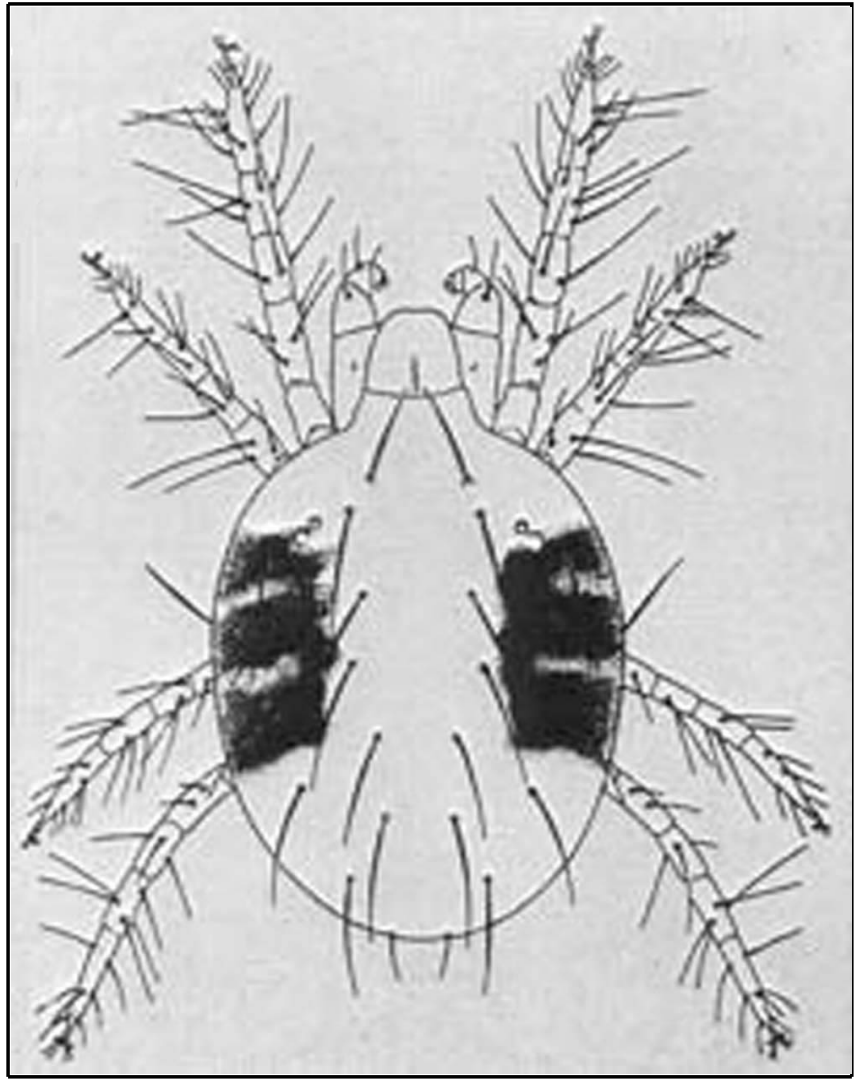

Figure 1. Twospotted mite. Credits: University of Florida

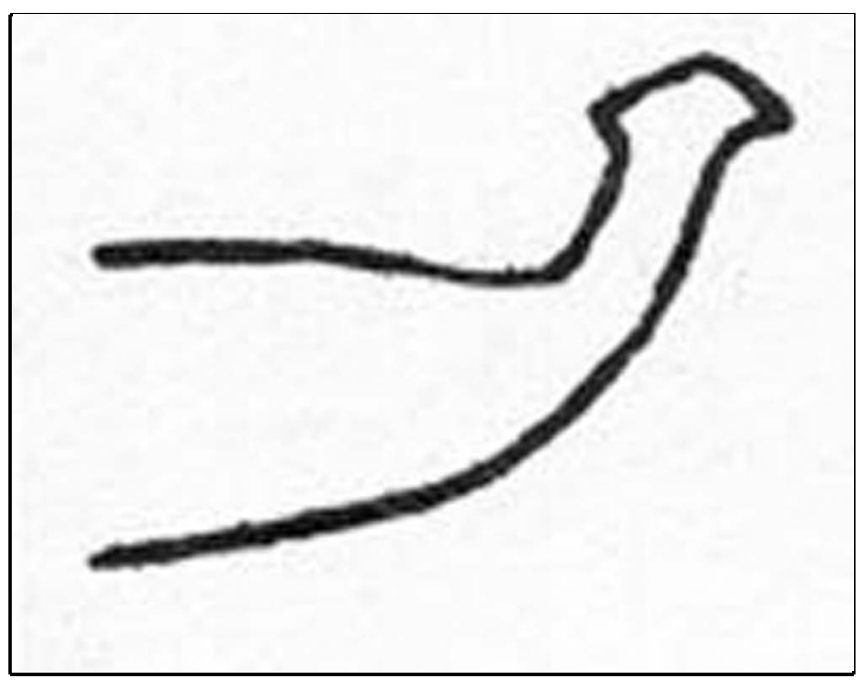

Figure 2. Male aedeagus. Credits: Division of Plant Industry

composed of the egg, the larva, two nymphal stages (protonymph and deutonymph) and the adult. The length of time from egg to adult varies greatly depending on temperature. Under optimum conditions (approximately 80 degrees F), spider mites complete their development in five to twenty days. There are many overlapping generations per

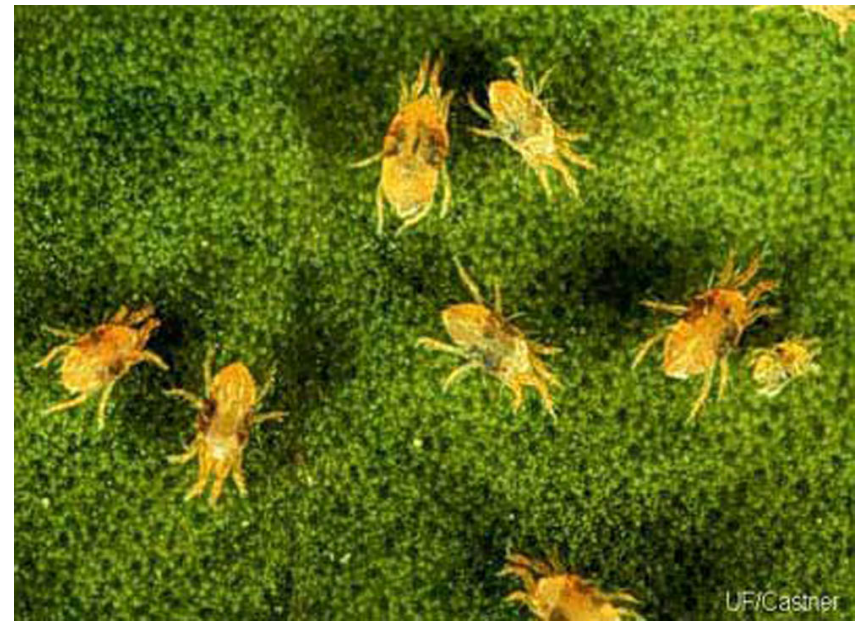

Figure 3. Twospotted spider mites, Tetranychus urticae Koch. Credits: University of Florida

year. The adult female lives two to four weeks and is capable of laying several hundred eggs during her life.

The twospotted spider mite prefers the hot, dry weather of the summer and fall months, but may occur anytime during the year. Overwintering females hibernate in ground litter or under the bark of trees or shrubs.

\section{Economic Importance}

Spider mites are the most common mites attacking woody plants and the twospotted spider mite is considered to be one of the most economically important spider mites. This mite has been reported infesting over 200 species of plants. Some of the more ornamental common plants attacked include arborvitae, azalea, camellia, citrus, evergreens, hollies, ligustrum, pittosporum, pyracantha, rose, and viburnum. Fruit crops attacked include blackberries, blueberries and strawberries. A number of vegetable crops such as tomatoes, squash, eggplant, cucumber are also subject to twospotted spider mite infestations and damage. The mite is also a pest of trees and may damage maple, elm, redbud and has been reported on ash black locust and popular. It has been occasionally found on other trees (Johnson 1991).

The twospotted spider mite is also a serious pest in greenhouses as well as on field grown chrysanthemums. The mites generally feed underneath the leaves and cause graying of the leaves 
due to mesophyll collapse and yellowing. Necrotic spots occur in the advanced stages of leaf damage. Mite damage to the open flower causes a browning and withering of the petals that resembles spray burn.

All mites have needle-like piercing-sucking mouthparts. Spider mites feed by penetrating the plant tissue with their mouthparts and are found primarily on the underside of the leaf. All spider mites spin fine strands of webbing on the host plant--hence their name.

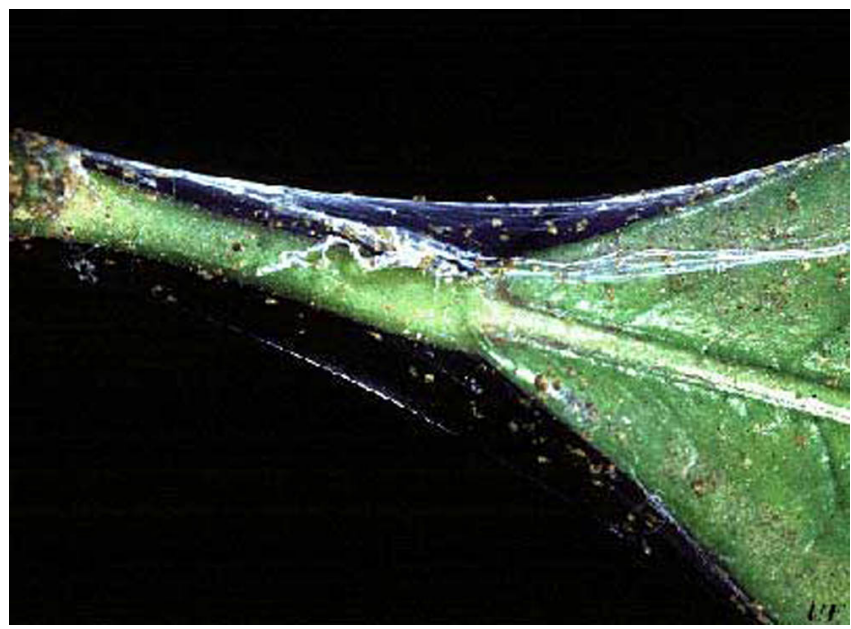

Figure 4. Webbing produced by twospotted spider mites, Tetranychus urticae Koch. Credits: University of Florida

When twospotted spider mites remove the sap, the mesophyll tissue collapses and a small chlorotic spot forms at each feeding site. It is estimated that 18 to 22 cells are destroyed per minute. Continued feeding causes a stippled-bleached effect and later, the leaves turn yellow, gray or bronze. Complete defoliation may occur if the mites are not controlled.

\section{Management}

For detection of spider mites, a $10 \mathrm{X}$ to $15 \mathrm{X}$ magnifying glass is a necessity. Examine the undersides of the leaves closely for mites, cast skins and webbing. A more efficient technique is to place a sheet of white typing paper beneath the leaves and strike the foliage sharply. The mites will fall onto the paper and can be more easily observed and identified than on the green foliage.

Predators are very important in regulating spider mite populations and should be protected whenever

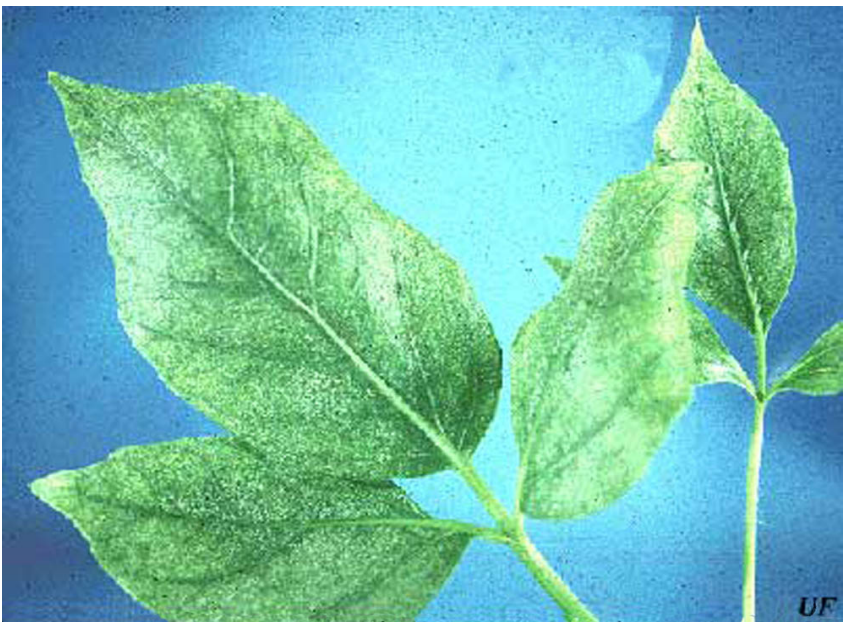

Figure 5. Damage caused by the twospotted spider mite, Tetranychus urticae Koch. Credits: University of Florida

possible. Important genera include the predatory mites, Amblyseius, Metaseiulus, and Phytoseiulus, the lady beetles, Stethorus, the minute pirate bugs, Orius, the thrips, Leptothrips, and the lacewing larvae, Chrysopa.

Spider mites are commonly attacked by predator mites. Five species are commercially available in the U.S.: Phytoseiulus persimilis, Mesoseiulus longipes, Neoseiulus californicus, Galendromus occidentalis and Amblyseius fallicus. Predatory mites can be distinguished from spider mites because of their longer legs. The front pair of legs is often extended forward. They are more active and move about at a fast pace. They are often red or orange in color. $P$. persimilis is the most common predator and preys on all stages of mites (Osborne 1999). It can consume 20 eggs or five adults daily.

Overwintering mites may be reduced in numbers by the destruction of weeds such as pokeweed, Jerusalem oak, Jimson weed, wild blackberry, wild geranium and others.

Insecticidal soaps and oils should be carefully considered when a pesticide is required. They are effective against mites and the least toxic to people, other non-target organisms and the environment. The effectiveness of laundry soaps, washing detergents, and vegetable oils is less consistent than with chemical pesticides. Although some growers have been quite pleased with the results of non-insecticidal quality soap and oil use, some have been disappointed. Also, plant varieties differ in their 
susceptibility to burning induced by soaps and oils.

Environmental conditions, as well as micronutrients, fertilizers, and other additives may affect a tendency to "burn" foliage. At higher rates of application, $(2 \%)$, burning and stunting are more likely (Capinera 1992).

The twospotted spider mite develops a resistance to most acaricides after prolonged use. Most miticides are not effective on eggs. Therefore two or more applications of the miticide will be required at five-day intervals during the summer or seven-day intervals during the winter.

Insect Management Guide for Turf and Ornamentals

Insect Management Guide for Vegetables

Insect Management Guide for Fruit Crops

\section{Selected References}

Capinera, J.L., and O.N. Nesheim. (March 1992). Soaps and detergents for insect control. Pest Alert.

http://extlab7.entnem.ufl.edu/PestAlert/jlc-0316.htm (8 August 2000).

Johnson, W.T., and H.H. Lyon. 1991. Insects that feed on trees and shrubs. 2nd ed., rev. Comstock Publishing Associates. 560 p.

Metcalf, R.L. and R.A. Metcalf. 1993. Destructive and Useful Insects. 5th Edition. McGraw-Hill, Inc. New York.

Mizell, R.F., D.E. Short and T.R. Fasulo. (1999). Spider mites. WoodyPest.

http://woodypest.ifas.ufl.edu/mites.htm (5 June 2000).

Osborne, L.S., L. E. Ehler, and J. R. Nechols. (July 1999). Biological control of the twospotted spider mite in greenhouses.

http://www.mrec.ifas.ufl.edu/lso/SpMite/b853a1.htm (13 September 2002).

Tuttle, D. M. and E. W. Baker. 1968. Spider mites of southwestern United States and a revision of the family Tetranychidae. Univ. of Arizona Press. $143 \mathrm{p}$. 